$\begin{gathered}\text { EPiC Series in Built Environment } \\ \text { Volume 2, 2021, Pages 201-209 } \\ \text { ASC 2021. 57th Annual Associated Schools } \\ \text { of Construction International Conference }\end{gathered}$
Built
Environment

\title{
Expert Witness Testimony in Construction Litigation by Construction-Area Faculty
}

\author{
Neil Opfer \\ University of Nevada, Las Vegas \\ Las Vegas, NV
}

\begin{abstract}
A common component in construction litigation in the United States and throughout the world is the use of expert witnesses typically by both the plaintiff and defense. In the U.S., constructionarea faculty often may be asked to serve as experts in these construction disputes. While many construction-area faculty members are aware of this practice area, due to a lack of understanding of requirements for experts, they may have not fully considered the benefits of being an expert in terms of career development, industry contact, and other areas. Interviews were conducted with several construction-area faculty members that serve as experts in construction disputes possessing significant experience in this area. The goal was to examine both requirements and benefits for the faculty member who acts as an expert witness. These requirements include verbal/written communication skills, background knowledge, research/analytical ability, and presentation ability before arbitrators, judges, and juries. The benefits besides obvious financial compensation include continued industry experience and contact along with keeping abreast of industry practices. The expert experience of these faculty members in construction litigation disputes was centered on construction safety/accidents, construction defects, construction contracting issues, construction scheduling issues, and construction cost issues.
\end{abstract}

Key Words: construction litigation, expert witness, faculty practice

\section{Introduction}

The construction industry is a significant industry in the United States. The U.S. construction industry has more than 680,000 employers with over 7 million employees with a volume of over $\$ 1.3$ trillion worth of structures each year (AGC, 2020). In addition, there are 1.3 million attorneys also present in the United States (ABA, 2018). A significant number of these attorneys are employed in construction litigation. A survey in 2011 found that the average construction dispute in the U.S. was \$10.5 million (Zack, 2012). Given the complexities inherent in the typical construction project, it is not surprising that construction litigation would also be a significant factor with many of these projects. Attorneys in this construction litigation often turn to experts to assist them in these construction litigation issues. Over the years, the author has encountered several construction faculty members who act as experts in these issues. 
A literature search in the area of expert witnesses will quickly find numerous books and articles on this specific topic. This author has reviewed a number of these published references over the years. Faculty members in general and not specifically in construction who act as expert witnesses also find limited topical coverage in this area. However, this author, in evaluating this construction-practice idea, despite extensive literature searches, could find no on-point discussions of construction-faculty experiences in this area. This was somewhat surprising, as an unexplored topic, given the discussion of construction disputes often seen in construction-management textbooks.

Therefore, in view of this, the author conducted a qualitative survey by phone of six experts that are also construction faculty known to be working in construction litigation. As a result of these contacts, the six faculty members in return referred several more faculty members that they knew that were acting as experts in construction litigation. In two cases, these additional contacts were the same faculty member. The net result was that twelve faculty members in total were interviewed for this paper. This number of interviewees therefore represents a limited sample size although the accumulated-expert-witness experience totals 162 years.

\section{Expert-Witness Overview for Construction Litigation}

Expert witnesses are utilized in order to assist triers of fact (judges, juries, arbitrators) to better understand issues beyond a layperson's understanding. In essence, an expert witness acts as a consultant to the legal system. The experiences that resulted from those of the experts interviewed are based on their widespread experience across the United States. However, even within the fifty states of the U.S., requirements vary widely depending on state laws and associated regulations. Since requirements vary by jurisdiction so those working in this area must consult applicable state laws and regulations for relevant practices. It will be assumed that the expert witness requirements include an expert report, deposition testimony, and further testimony such as in court or at arbitration. Despite popular impressions cultivated in television and the movies, in the vast majority of litigation matters, cases settle out of court without a trial. At a construction conference, one state-court judge who had retired remarked that in a given year he would have 30,000 cases in his docket (Davis, 2014).

Obviously the vast majority of these cases have to settle out as there would obviously be no time for this judge to preside over 30,000 cases in a year. Usually, the expert witness is retained by one of the parties in the litigation matter. However, it is recognized that, at times, the expert witness may be jointly retained by the two sides or retained by a court or arbitration panel to assist these triers of fact to understand the competing contentions. These expert witnesses can be part of a team when more complex cases require more varied backgrounds. In some instances, a person becomes an expert witness, almost by accident, when, for example, they are contacted by a client such as an owner, contractor, or attorney to assist them with a litigation matter. The expert witness needs competence in their chosen professional area along with the ability to write competent technical reports. The expert witness needs the verbal communication skills in depositions and legal venues such as at trial to explain their analysis. The work of the expert witness must, as well, conform to high ethical standards as exemplified in the ethical codes seen with most professional associations.

\section{Expert Interview Questions}

The questions asked of each faculty member are seen below in Table 1 . The survey initially started off with Questions 1 - 5 and then Questions 6, 7, 8, and 9 were added based on initial responses. Due to this, those experts interviewed at first were then re-contacted to get their responses to the additional questions to ensure a complete result. 
Table 1

Questions For Interviewing Purposes

\begin{tabular}{|c|c|}
\hline $\begin{array}{l}\text { Question } \\
\text { Number }\end{array}$ & Question Topic \\
\hline 1 & $\begin{array}{l}\text { How did you get into the field of an expert witness concerning construction } \\
\text { litigation? }\end{array}$ \\
\hline 2 & $\begin{array}{l}\text { What is your background as to years of expert witness experience, years of } \\
\text { academic/industry experience, area of country, and academic rank? }\end{array}$ \\
\hline 3 & What areas do you provide expert services for in construction litigation? \\
\hline 4 & $\begin{array}{l}\text { What do you consider to be the most important skills/abilities for an expert } \\
\text { witness such as yourself? }\end{array}$ \\
\hline 5 & $\begin{array}{l}\text { What credentials, if any, besides academic/construction industry experience do } \\
\text { you have related to your expert work? }\end{array}$ \\
\hline 6 & What do you consider to be the advantages of being an expert witness? \\
\hline 7 & What do you consider to be the disadvantages of being an expert witness? \\
\hline 8 & What is your institution's policy towards consulting including being an expert? \\
\hline 9 & $\begin{array}{l}\text { How do potential clients find out about your offering of services as an expert } \\
\text { witness? }\end{array}$ \\
\hline
\end{tabular}

\section{How These Faculty Became Involved in Expert-Witness Work}

So how does one get started as an expert witness? In construction litigation, the obvious participants are construction attorneys. The client of the attorney may be a contractor, owner/developer, design firm, or other participant. In interviews, 10 of the 12 indicated that they were first contacted by either an attorney or someone such as an owner or contractor. In 2 of these 10 first contacts, one of their students working on behalf of a contractor in one case and a developer in another case had recommended the faculty member as an expert. The other 2 experts indicated that they were working for a consulting-engineering firm and the matter of acting as an expert more or less fell into their lap as part of their assigned duties. No one indicated that they had ever planned on being an expert before they became involved in this work. In the usual cases, it was indicated that an attorney may first request a resume or $\mathrm{CV}$ for approval by their client. At the same time, the attorney wants to know if, after outlining the basic issues in the case, whether the person contacted as an expert has the requisite background. The attorney will also want to know if there are any conflicts with one or more of the case parties.

\section{Expert Background/Demographic Information}

Table 2 information relates to demographic/background information obtained from the interview process. The experts were asked as to key information in both their experience as an expert and their academic/construction experience. In addition, their rank was ascertained in this process. As seen in Table 2, the number of years of expert witness experience ranged from a low of 5 years to a high of 30 years with an average of 13.5 years. Academic/industry experience in this context means any combination of years as a faculty member teaching coursework/conducting research or experience in the construction industry and this number ranged from a low of 11 years to a high of 41 years with an average of 22.25 years. Academic rank of the 12 experts interviewed were 4 faculty at the Associate Professor Level, 6 faculty at the Professor Level and two faculty retired at the Professor Emeritus Level (one Associate and one Professor). These 2 Professor Emeritus Faculty were still performing expert work and given their extensive backgrounds plus recent retirements were included in this work. 
The expert experience was found to overlap the academic/industry experience and 10 of 12 experts indicated that they had started work as experts after they had taken their academic positions. In 2 instances, the experts had done some expert work prior to taking a faculty position. In all instances, faculty members had started their work as an Assistant Professor and then promotions followed to the next level as Associate Professor or subsequently as Professor. The interviews found that most viewed being an expert while working as an Assistant Professor to be problematic given the initial time demands to prepare class work when first starting out and demands during the tenure process such as research/publication work. Once classes have been established, the experts indicated that time became available for expert work. The experts also indicated that as they gained academic experience that their time-management skills became better as to setting up both homework and tests to improve grading efficiency. Further along in their academic career with more experience in classes also academic coursework became easier to teach as they gained subject knowledge.

Table 2

Interviewee Background Data

\begin{tabular}{|c|l|l|l|l|}
\hline $\begin{array}{c}\text { Interviewee } \\
\text { Number }\end{array}$ & $\begin{array}{c}\text { Region Of } \\
\text { United States }\end{array}$ & $\begin{array}{c}\text { Expert Witness } \\
\text { Experience* }\end{array}$ & $\begin{array}{c}\text { Academic / } \\
\text { Construction } \\
\text { Experience* }\end{array}$ & Academic Rank \\
\hline 1 & West & 10 years & 21 years & Assoc. Prof. \\
\hline 2 & West & 8 years & 25 years & Professor \\
\hline 3 & Midwest & 10 years & 18 years & Professor \\
\hline 4 & Southeast & 26 years & 35 years & Prof. Emeritus \\
\hline 5 & Northeast & 11 years & 15 years & Assoc. Prof. \\
\hline 6 & West & 14 years & 21 years & Professor \\
\hline 7 & Midwest & 10 years & 15 years & Assoc. Prof. \\
\hline 8 & Midwest & 9 years & 23 years & Professor \\
\hline 9 & West & 12 years & 20 years & Professor \\
\hline 10 & Northeast & 30 years & 41 years & Prof. Emeritus \\
\hline 11 & Southeast & 17 years & 22 years & Professor \\
\hline 12 & Midwest & 5 years & 11 years & Assoc. Prof. \\
\hline & Average & 13.5 years & 22.25 years & \\
\hline & Experience & & & \\
\hline
\end{tabular}

*Note that the two categories of Expert Witness Experience and Academic/Industry Experience overlap with each other except in the partial situation with the two Professors with Emeritus Status.

\section{Case Areas/Specializations Of The Interviewed Experts}

Table 3 below shows the respective areas where the 12 experts practice which are construction safety/accidents, construction defects, construction scheduling/schedule impacts, construction estimating/construction costs, and construction contracts. The column boxes are filled in as $\triangle$ YES where practice areas are present and left blank where no work is performed by that expert. At the outset, the five categories were not set but Question 3 was created as open-ended and then the subject interviews developed the information to set the categories. Five of the experts noted that they concentrate on only a single area with 2 practicing in the safety/accidents' area, 1 expert in the construction defects' area, and 2 experts in the construction scheduling/schedule impacts' area. The other 7 experts had two or more areas of expertise. The interviewed faculty members noted that their expertise in these areas of specialization either derived from their industry experience or their academic background in teaching certain classes such as in the areas of safety, cost estimating and scheduling or with a combination of academic and industry experience. 
A few of the experts explained that in more complex cases, expert witness testimony may be provided by more than one person due to the assignment's broad scope. As an example, a complex construction claim may require the services of a scheduling expert, an estimating expert, a construction defects' expert and others depending on the extent of case issues. These experts indicated that a key concept is to not go outside your area of expertise and recommend the use of others to the client. Since these experts are also full-time faculty members, three experts indicated that a sound practice is to also weigh time demands because the case extent may be such that case demands versus the time available to the faculty member restrict practice scope. One expert noted that when contacted on a case that the time demands and key case dates are a key factor in determining whether to take on that case assignment. Experts noted they need to be respectful of their institution and that they do little good to turn out incomplete work due to time limitations.

Table 3

Interviewee-Expert Concentration Areas

\begin{tabular}{|c|c|c|c|c|c|}
\hline $\begin{array}{l}\text { Interviewee } \\
\text { Number }\end{array}$ & $\begin{array}{l}\text { Safety/ } \\
\text { Accident } \\
\text { s }\end{array}$ & $\begin{array}{c}\text { Constructio } \\
\text { n Defects }\end{array}$ & $\begin{array}{c}\text { Construction } \\
\text { Scheduling/Schedul } \\
\text { e Impacts }\end{array}$ & $\begin{array}{l}\text { Construction } \\
\text { Estimating/ } \\
\text { Costs }\end{array}$ & $\begin{array}{l}\text { Constructio } \\
\text { n Contracts }\end{array}$ \\
\hline 1 & $\Delta$ YES & & & & \\
\hline 2 & & $\triangle \mathrm{YES}$ & & & \\
\hline 3 & & & $\Delta$ YES & $\Delta$ YES & \\
\hline 4 & & & $\Delta$ YES & $\Delta$ YES & $\Delta$ YES \\
\hline 5 & & & & $\Delta$ YES & \\
\hline 6 & $\Delta$ YES & & & & \\
\hline 7 & & & $\Delta$ YES & & \\
\hline 8 & & & $\Delta$ YES & $\Delta$ YES & \\
\hline 9 & $\Delta$ YES & $\Delta$ YES & & & \\
\hline 10 & $\Delta$ YES & & & & \\
\hline 11 & & & $\Delta$ YES & & \\
\hline 12 & & $\Delta$ YES & & & $\Delta$ YES \\
\hline $\begin{array}{l}\text { Column } \\
\text { Totals }\end{array}$ & 4 & 3 & 5 & 4 & 2 \\
\hline
\end{tabular}

\section{Essential Expert Skills and Abilities}

The requirements for an expert witness as noted in these interviews are many. The experts noted that the background of the expert witness, based on education and experience, should be that wherein one can competently analyze the issues involved and report back, in a verbal and later a written fashion outlining the relevant issues. They also noted that the expert witness should be someone who can explain to those in the relevant forum (judge, jury, arbitrator, etc.) the issues involved in a particular dispute based upon the expertise provided by that individual which is based primarily upon the witnesses' expert report regarding the dispute issues. The expert may be jointly retained by both sides (plaintiff and defense) in a dispute or more commonly where both sides may retain their own expert(s). In some instances an expert witness may be brought in upon the agreement of both sides as a third party to objectively analyze the relevant positions. All noted that the ability to write a competent technical report was the most important skill/ability. Secondly the experts also noted that sound verbal skills were important to be able to explain to first a client or clients and then to others such as arbitrators, judges, and juries the key aspects of the case. Underlying these requirements is the ability to be organized and meet requisite legally-imposed court deadlines. 
The experts explained that expert witnesses should be careful in their case selection and client selection. Situations were noted where one side is simply representing a poor position. This may not at first be apparent that the client is decidedly in the wrong but, when first discovered, the expert needs to communicate this to the client. An expert, as an example, told of being contacted by an attorney on a construction safety case where this expert had been working on other construction cases for this same client for approximately five years. The attorney outlined the case and this expert's analysis was that one particular party was at fault and then several reasons were cited why this party was in this unfavorable position. Noticeably the attorney became quiet and then finally said that his client was the particular party that had just been criticized by the expert as to their safety practices. It did not matter to this expert as the analysis would still be the same. Finally the only thing the attorney asked was a referral to another expert in this area. The hallmark of an ethical expert witness is pointing out the flaws in a particular assignment and avoiding involvement with bad cases.

\section{Credentials Possessed by these Interviewed Experts}

The experts explained that qualifications for an expert witness typically revolve around experience in the relevant field (academic/industry), certifications, licenses, and appropriate academic degrees. The faculty expert may run into other selected experts that may have no certifications, licenses, or degrees but simply have substantial experience in the necessary area or areas. Based upon the previous discussion regarding the selection of a scheduling expert and estimating expert on a complex construction claim, one individual with a diversified background in both estimating and scheduling may be able to satisfy the requirements in this area. Having no degrees, licenses, or certifications can be commonplace in a dispute involving construction practice where the relevant qualifier may be trade experience in a given area such as carpentry or concrete construction. The degrees of the subject experts in these interviews found master-degree level as a minimum up to those experts with a doctorate.

Credentials besides degrees and relevant experience include certifications and licenses. In terms of licenses, the typical licenses involved in construction disputes are contractor's licenses, engineering licenses, architecture licenses, and other specialty licenses such as a certified public accountant (CPA). Licensing is a typical state function and valid only within that state whereas certifications are granted by professional organizations and not restricted to state boundaries. The lack of a license or a certain certification may not be a disqualifying factor. However several of the interviewed experts noted that if the other side's expert(s) in a dispute has (have) these types of certifications, that expert without this background may simply look less qualified in the eyes of judges, juries, or arbitrators. In some cases, the expert's ability to testify may not be allowed in certain forums due to the lack of these qualifications. An expert may be extremely well-qualified in terms of scheduling work over a long career but a certification "proves" that that expert has the necessary qualifications and has passed a rigorous exam. What qualifications such as certifications means for those in the expert-witness area is that these credentials substantiate the expert's credibility.

The experts also noted that once obtained, the expert should ensure that these credentials are appropriately maintained as the benefits are lost if the credentials are allowed to lapse. As an example, many certifications must be renewed every three years. This renewal is through a combination of continuing experience and continuing education/service on credit plans that ensures that the certificate holder stays up-to-date in their respective field. The expert witness should also strive to continually be well-informed in their respective field(s) through attendance at professional meetings, conferences, and the review of publications. These experts noted instances of other experts being questioned as to 
current background where that person's last professional conference turns out to have been twenty years ago.

\section{Advantages of Expert-Witness Work}

In expert work, a few of the experts noted the financial benefits in their roles as expert witnesses. One noted that without their expert-consulting income that they would have to abandon their academic career and return to private industry given the relatively low salary levels at their institution. Others noted that with expert income that they were able to fund needed activities for their classes or to fund graduate students to work on "bootstrap" research that would otherwise not take place. With the results from this "bootstrap" research, they would then be able to obtain adequate grant funds to expand upon this research. Many academic construction programs are significantly underfunded and therefore a portion of what faculty members receive can be a needed supplement. Most experts considered the most significant benefits of expert work to be the actual involvement in the construction industry and to keep current with the industry. Experts pointed out that they have gained ideas for publishing articles or pursuing research based upon learning new information that was either related or in many instances not related to a case assignment. Since they were on the subject case assignment, they learned this information and they were able to utilize this either in classes or in a published article. If the expert was not doing the expert work, they would not have been exposed to these insights and information. Experts also pointed out that by doing a sound job in their work that they were helping out people to obtain a just result either in an arbitration forum or in court.

\section{Disadvantages of Expert-Witness Work}

A factor cited by all experts in this work were the associated time pressures with these tasks. Those faculty members not working in a major metropolitan area such as a Phoenix or an Atlanta but remotely from an isolated-university campus find these time pressures include travel. A few experts noted that deadlines for expert reports or deposition/court dates often fall at the most inopportune times. As a consequence of the time pressures, this results in elevated stress levels. Two experts stated that additional frustrations can result from clients either completely not paying bills or significant delays with getting paid on various cases. It was explained that lack of payment is particularly frustrating when the expert has significant out-of-pocket costs for hotel and other travel costs. Several of the experts noted that if they are not familiar with a client that prior to starting work they demand a retainer fee upfront sufficient to cover their anticipated time and costs. The advice here was to avoid bad clients because, at the outset, if a client cannot afford your retainer, you may never receive payment. A few experts cited examples of clients going bankrupt either due to claims' issues or just from general financial problems with the result of no payment. Approximately half of the experts pointed out the ethical issues with opposing experts that they found frustrating with an expert having one point of view in working for a plaintiff on one side of a case and then seeing that same expert take the completely opposite view when working for the defense. The experts in complaining said that sometimes the facts are not always the same but when they are, ethics demands that the ethical consultant reach the same conclusion.

\section{Benefits of Faculty Participation for Industry and Institutions}

Faculty members to be competent at their work spend a significant amount of time keeping posted in their subject areas. This faculty work, of course, includes reading publications along with other education. However, faculty, despite, their best efforts, can lose contact with the ever-evolving construction industry. Participation in construction litigation offers significant avenues for faculty to 
stay current with the industry which can strengthen academic courses. Unfortunately, in construction, there are numerous developments in construction practice that are not documented for a variety of reasons. Faculty can bring these developments back to their institutions to improve construction education which benefits the subject institution.

Faculty participation in construction litigation can benefit the construction industry in a variety of ways. The most obvious is assistance in ensuring an informed result from the construction litigation. The next is face-to-face exposure of the industry to the high quality of the typical construction-faculty member. The same would apply as well to litigation contacts with other attorneys, arbitrators, judges, and juries. Construction programs at academic institutions turn out thousands of graduates each year. Despite this construction graduates are "drowned out" in the overall construction industry by the even greater numbers of other graduates working in construction with other majors such as business, engineering, and architecture. Many in construction positions may have only trade experience. Faculty specifically noted that they felt their litigation-related work resulted in other benefits in marketing the quality of their construction programs to contractors and others involved in the litigation.

\section{Institutional Policies Towards Outside Work Including Expert-Witness Work}

As an expert witness, one must have a schedule that is flexible to allow participation in depositions and court cases. All those interviewed indicated that their respective institutions allowed outside consulting work including expert-witness work insofar as it did not interfere with the other duties of the faculty member including teaching responsibilities. All experts indicated that their institutional policies allowed faculty to consult for one day per week. These faculty members who act as expert witnesses noted that this is a key policy because their institutions allow this certain amount of consulting work at one day per week and also because their jobs contain a certain degree of schedule flexibility. If one does not have some degree of schedule flexibility it was noted by those interviewed that trying to be an expert witness is typically much more problematic because, most often, depositions, arbitrations, and court trials occur during normal week-day business hours. Those involved in litigation whether attorneys, arbitrators or judges realize that most experts whether at a university or otherwise have busy schedules and so therefore will adjust schedules to accommodate the other responsibilities of faculty members. Obviously today's digital world with email, file-share software, video conferencing, plus overnight delivery mean that for substantial parts of expert work that the expert can be anywhere in the U.S. However, that expert still will be required to be present at a trial or arbitration or deposition or to conduct a site visit. Faculty members still must have a presence on campus for classes and other responsibilities at their institutions. When conflicts take place, other colleagues or graduate students may be have to act as substitutes or proctor exams.

\section{How Experts Get Cases/Find New Work}

The experts interviewed all agreed that their key to gaining expert work was to do a solid job on every expert assignment. Based on this work, referrals for additional work then follow from the original or initial case assignment. These experts indicated that if an expert is not gaining substantial work from repeat assignments, the expert should carefully try to ascertain any potential reasons why this workreferral process may not be taking place. Two experts noted that law firms like other firms have turnover issues therefore when attorneys familiar with that expert leave and other attorneys come in, there may be a disconnect that causes the expert to miss out on work. It was also indicated that attorneys in leaving may go to another firm where they are working on cases whose subject matter is not within that expert's experiential background anymore. In some instances, other attorneys 
representing the other side in a dispute may find the opposing experts' work of such quality that they then hire that faculty expert for other cases which is an added benefit of doing a sound job.

So how does one get case assignments if they have no litigation experience? One expert noted that one may look at experienced experts and feel that they could never measure up. However, at some point, each of these experts started at ground zero. Everyone starts here until they gain experience. Some attorneys may only want experienced experts but there are attorneys who want to retain as an expert someone with the necessary education and experience but little to no experience as an actual expert. No attorney ever wants to retain an "expert" who is not familiar with the subject matter in a given area. These attorneys may even feel better about these types of experts because of the lack of a legal track record (deposition/trial testimony) that could be used against their expert.

Some of the experts indicated that they are listed as experts with various firms that provide experts in litigation matters. It was indicated that often contractor associations have as associate members those law firms that specialize in construction litigation. Therefore these experts sent out resumes to these law firms highlighting their abilities as experts in construction litigation.

\section{Conclusion}

The purpose of this work was to provide a better understanding of expert-witness work on construction litigation on the part of construction-area faculty members. The expert witness in complex construction litigation is often essential to helping arbitrators, judges, and juries to properly understand the issues in these disputes. The 12 experts interviewed in this work possessed an average of 13.5 years of expert experience and an average 22.5 years of combined academic/industry experience. The overall sample size is small in this initial work but still represents 162 years of litigation experience. Further research in this area would include obtaining additional interviews with other experts to verify the findings found in this initial work.

These experts explained the issues revolving around faculty members in being expert witnesses in this area including advantages and disadvantages with this role. Faculty members felt that this work helped them to stay current with numerous industry developments that go undocumented for a variety of reasons. This practice area can also both benefit the construction industry through more-informed litigation results and help programs through improved course content along with indirect marketing.

\section{References}

ABA (2018). "New ABA data reveals rise in number of U.S. lawyers, 15 percent increase since 2008." Retrieved from $<$ https://www.americanbar.org/news/abanews/aba-newsarchives/2018/05/new_aba_data_reveals/>

AGC (2020). “Construction Data.” Retrieved from < https://www.agc.org/learn/construction-data\#>

Davis, E. (2014). “Complex Construction Litigation.” Lorman Education Seminar, Las Vegas, Nevada.

Zack, J.G. (2012). "Trends in Construction Claims \& Disputes A Research Perspective Issued by the Navigant Construction Forum, Value and Duration of Construction Disputes": 4. Retrieved from <https://www.cmaanet.org/sites/default/files/resource/Trends> 